\title{
Translations of the Sacred City between Jerusalem and Rome
}

\author{
Sible de Blaauw
}

Several cities and individual churches in the Middle Ages were associated with the idea of representing or incorporating Jerusalem in one manner or another. This widely attested phenomenon occurred in a large range of variants, depending on the 'type' of Jerusalem represented and the way in which the representation was made concrete. ${ }^{1}$ In this contribution, I aim to discuss one of the earliest, and perhaps one of the most notable cases of 'being' Jerusalem outside Jerusalem. The church leaders of Rome may have had very specific reasons for appropriating the significance of the historical Jerusalem as the ancient capital of the Roman Empire. Moreover, they may have utilized very specific instruments in order for this claim to materialize. It was rooted in the idea that Christian Rome had been founded directly from Jerusalem by the mission of the apostles Peter and Paul. Rome was, in the words of Jennifer O'Reilly: 'the western extremity of their evangelizing mission from the biblical centre of the earth at Jerusalem and became the new centre from which their papal successors continued the apostolic mission to the ends of the earth.' The existence of the apostles' tombs, reinforced by the recollections of numerous Christian martyrs, was the fundamental factor in making Rome into the new spiritual capital of the Christian world. This claim urged Christian Rome to establish new terms for its relationship with what qualified, perhaps, as 'the ideological centre of the Christian empire' in Jerusalem. ${ }^{3}$ It has been argued that the Roman Church did so by a literal transfer of the significance of earthly Jerusalem to Rome, and hence by making Jerusalem superfluous. Hartmann Grisar's 1899 essay 'Antiche basiliche di Roma imitanti i santuarii di Gerusalemme e Betlemme' contained stimulating ideas and observations, which have largely been reproduced by later scholarship, often, however, without critical evaluation of the evidence. ${ }^{4}$

1 E.g. Kühnel 1987 and Ousterhout 1998.

2 O'Reilly 2007, p. 13; cf. O'Reilly 2003, pp. 148-50.

3 Elsner 2000, p. 194.

4 Grisar 1899.

(C) SIBLE DE BLAAUW, 2014 | DOI 10.1163/9789004270855_008

This is an open access chapter distributed under the terms of the Creative Commons AttributionNoncommercial 3.o Unported (CC-BY-NC 3.0) License. 
In the following pages, the visual and material means employed to link Jerusalem or ideas of Jerusalem to the physical city of Rome in Late Antiquity and the Middle Ages will be examined. Buildings, topography, iconography and liturgy in Christian Rome comprised various images and reflections of Jerusalem. The investigation will concentrate on the most conspicuous and consistent examples of references to the earthly Jerusalem, which represent a variety of 'media', including relics, visual representations, locations and ceremonies. These quotations or allusions may also refer to the Heavenly Jerusalem, but this level of interpretation needs no inclusion in the present argument. The discussion starts in Constantinian times and ends in the period of the overwhelming increase of ideas about, and memories of, Jerusalem produced all over Western Europe as a result of the Crusades. For obvious reasons, the Roman Church which is itself called 'Jerusalem', Santa Croce in Gerusalemme, will claim a central role in the ensuing discussion.

\section{The Earliest Relic from the Holy Land?}

The building programme of the emperor Constantine, ruling over the city of Rome from 312 until his death in 337, included the first all-embracing project of architectural and urbanistic Christianization of the ancient capital. ${ }^{5}$ The new, public buildings for Christian worship were destined for different functional categories: the urban cathedral of the Lateran, the memorial basilica of St Peter's on the Vatican hill and funerary basilicas on the Christian cemeteries outside the walls. One of Constantine's foundations, however, was exceptional in all respects. It was a church (basilica) installed in an existing building, the Sessorian palace, and it was allocated to the veneration of a relic brought from afar, a fragment of the wooden cross on which Jesus of Nazareth had been crucified (Fig. 6.1). ${ }^{6}$ Both the reuse of an older building and the cultic focus on a translated relic are unique in Constantine's building activities in favour of the Christian Church, including his projects in the Holy Land and the new capital of Constantinople. The Roman editor of the early sixth century, who made use of original archival documents concerning Constantine's church foundations to compile the Liber Pontificalis, the book with the biographies of the Roman

5 Recent overview: Brandenburg 2004.

6 LP 34 c. 22: 'Eodem tempore fecit Constantinus Augustus basilicam in palatio Sessoriano, ubi etiam de ligno sanctæ Crucis domini nostri Iesu Christi in auro et gemmis conclusit, ubi et nomen ecclesiæ dedicavit, quæ cognominatur usque in hodiernum diem Hierusalem [...]' 


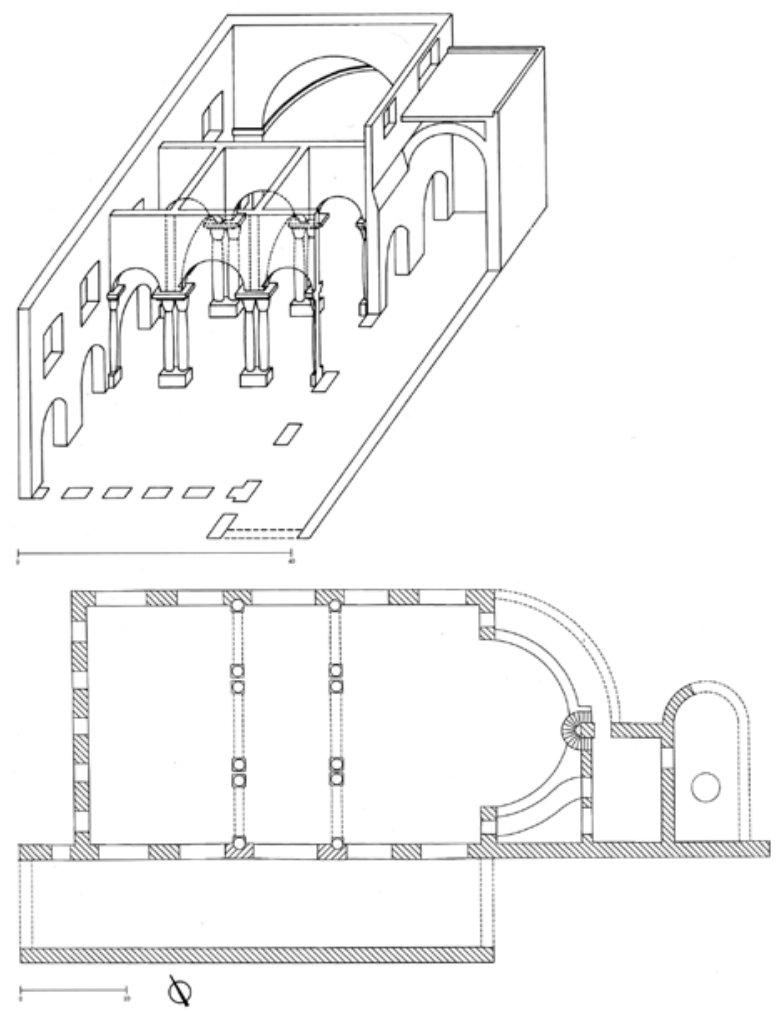

FIGURE 6.1 Rome, S. Croce in Gerusalemme, ca. 320-50, reconstruction of fourth-century plan and elevation (AFTER KRAUTHEIMER AND CECCHELLI).

bishops, did not fail to add that the church in question was entitled Hierusalem 'until the present day'.

The intricate layers of traditions regarding the Finding of the True Cross, the role of the empress Helena, Constantine's mother, and the diffusion of Cross relics and their cult over the empire in the course of the fourth century have obscured the significance of the facts regarding Rome. The early installation of a memoria of the Holy Cross in an imperial palace complex in Rome is extremely plausible, in view of sound written and archaeological evidence. ${ }^{7}$ 'Early' means before the 35os, the period in which the legendary tradition of the Cross Finding and the pilgrimage of Helena (died 329/330) to the Holy

$7 \quad$ For brevity sake I refer to the arguments discussed in De Blaauw 1997. 
Land was constructed. ${ }^{8}$ The cult in Rome appears to belong to the protohistory of this famous legend: a moment when the value of the Holy Cross as a relic had been recognized and the proliferation of particles was about to start, but without an underpinning narrative. The foundation documents of the Roman memoria do not speak about Helena, even if the empress-dowager may have lived in the Sessorian palace. The church, basically a large rectangular hall with diaphragm colonnades and an apse at its eastern end, must have been founded during Constantine's reign, but may have been accomplished only under Constantine's sons, one or two decades after their father's death in $337 .^{9}$

The remaining hard evidence is remarkable enough. The creation of a $m e-$ moria of the Holy Cross in Rome is the first outside Jerusalem that is historically corroborated. From its arrival in Rome, the Cross relic was sealed in a casing of gold and jewels - mentioned by the Liber Pontificalis. Its most probable place of conservation was a chapel directly behind the apse of the church, decorated with mosaics on behalf of the reigning emperors in the period $425^{-}$ 44. This later became the chapel of St Helena. Accidentally or not, its disposition corresponded to the location of Golgotha in relation to the Constantinian basilica of the Holy Sepulchre complex in Jerusalem..$^{10}$ The aspect of topographical identification is reflected in the epithet Hierusalem, current at least from the fifth century onwards and henceforth expressed in the usual designation of the Church as the Holy Cross in Jerusalem (today: Santa Croce in Gerusalemme).11

8 Scholarly consensus confirms the construction of the Helena legend in Jerusalem around the middle of the fourth century or slightly later: Drijvers and Drijvers 1997, p. 13.

9 Brandenburg 2004, pp. 103-08.

10 Already noticed by Grisar 1899, pp. 557-58. The difference is the location of the Cross sanctuary: to the left of the apse in Jerusalem and to the right in Rome. Although the dispositions of the sanctuaries are opposite, both are situated on the south side. Cf. a possible parallel in Santa Croce, Ravenna, in the years of Galla Placidia (c. 430- $5^{0}$ ), who is also known as the patron of a decoration of the Roman chapel: Smith 1990, pp. 193-95. In Ravenna the possible location of a cult of the Cross is situated to the left, i.e. the north of the apse. Smith is wrong in supposing that the Roman chapel is situated to the left of the apse as well.

11 For the earliest source, an inscription of 425-44: De Blaauw 1997, pp. 56-59. For the history of Santa Croce in Gerusalemme see: Gerusalemme a Roma 2012. 


\section{Jerusalem as the Christian Sacred City}

The Roman relic belongs to the first stage of the perception of Jerusalem and the Holy Land as the memorial place of the Salvation on earth, for which the physical evidence of Christ's Cross was increasingly a vital notion. ${ }^{12}$ Constantine's patronage of building in the Holy Land after $325 \mathrm{AD}$, early pilgrimage movements and the first diffusion of Cross relics confirm the growing consciousness of the sacred topography of Jerusalem in the 330 and $340 s .{ }^{13}$ In a wider context, this development may be seen as an episode in the redefinition of Christian identity in the Roman Empire, where Christian communities had been minorities suffering under suppression only recently, and now became part of an imperial project to make them participants in the legitimization of the emperor's authority. ${ }^{14}$ Although Constantine never visited Jerusalem as an emperor, and can hardly have nourished direct political interests for the inconsiderable provincial city, his cultural or religious commitment to local Christian sites is well documented. ${ }^{15}$ His position may have converged well with tendencies in the city's Christian community to establish a Christian dominated Jerusalem, which would erase Jewish and pagan recollections. ${ }^{16}$

Only in a second phase, reasonably linked with the policy and catechetical activity of Bishop Cyril from 350, was Christian cultural memory in Jerusalem redefined and assembled into the story of the Finding of the True Cross by Helena. Without doubt, use was made of the historical notions of the previous generation to which may belong the identification of the Cross of Christ under Constantine, as well as a journey of Helena to the Holy Land in 326. Helena's expedition was remarkable enough for an empress and a pioneering act of pilgrimage. The combination of these elements in one narrative, however, has many features of an invention of tradition. ${ }^{17}$ It spread continually over the empire, inspiring several variants in the East. Ultimately, in the 39os, the Helena legend was known in Italy. ${ }^{18}$ The idea that Helena found the True Cross of Christ in the direct vicinity of the very spot of the Crucifixion, and started the

\footnotetext{
12 Heid 2001[a], pp. 119-25.

13 Elsner 2000.

14 On the role of the Holy Land in this process: Jacobs 2004.

15 I am, however, rather sceptical towards the central role of the Holy Land in the 'construction of Christian imperial ideology' stressed e.g. by Elsner 2000 and Jacobs 2004.

16 Jacobs 2004, pp. 139-43.

17 Drijvers 1991, pp. 79-180, esp. pp. 138-45. The most recent evaluation of the sources and relevant scholarship: Heid 2001[b].

18 Drijvers 1992, pp. 109-13.
} 
distribution of its relics, would become the dominant story all over the Christian world in the Middle Ages.

Constantine had been willing to mark the urban area of Jerusalem and nearby Bethlehem with three conspicuous Christian buildings on the sites of Christ's birth, of his Teaching and of his Death and Resurrection. In the course of the century, these Constantinian memoriae became the nuclei of a landscape of loca sancta, holy sites, which made Jerusalem into a Holy City (Fig. 6.2). Its memorial geography of the history of Salvation attracted Christians from the whole empire and beyond. ${ }^{19}$ They visited places where biblical events themselves had taken place, spots where crucial moments in the history of Salvation could be experienced with the human senses in the most direct way. The accounts of early pilgrimages from the West to Jerusalem testify to the unique value of the Holy Land. An anonymous pilgrim from Bordeaux had already travelled during Constantine's reign, leaving the first written pilgrimage account (333 AD). Another pilgrim, Egeria, visited the Holy Land in the later years of Cyril's pontificate, and left a detailed diary (381-84 AD). The development of the cult of the Cross in half a century seems to be reflected in the way both authors refer to it. The first account only mentions Golgotha in passing, as the place of the Crucifixion close to the Holy Sepulchre, whereas Egeria describes the ceremonies of veneration of the Holy Cross extensively. ${ }^{20}$

The incomparable spiritual significance of the sacred topography of Jerusalem and the Holy Land was recognized in Rome during the fourth century, above all in ascetical circles. Jerome, the learned theologian, and aristocratic women like Paula and Melania the elder and the younger all left the busy capital and travelled to Palestine, to find a spiritual refuge in the direct vicinity of the holy places. ${ }^{21}$ Rome may have been blessed with the tombs of the apostles; a metropolis could not offer the ideal place for ascetic 'imitation' as the holy places in Palestine. ${ }^{22}$ In his letter to Marcella, Jerome stressed the particular sanctity of Jerusalem and did not hesitate to conclude that the city was even superior to Rome. ${ }^{23}$

19 For this development I was able to consult the recent, still unpublished Habilitationsschrift by Ute Verstegen, University of Erlangen 2013: 'Heiliger Ort - sakraler Raum. Kontinuität und Wandel in der Inszenierung der Herrenorte in Jerusalem'.

20 Itinerarium Burdigalense and Egeria 37 / 48 in: Itineraria 1965 CC 175, pp. 13-20, 80-81, 89.

21 Jenal 1995, pp. 350-52.

22 Hieronymus, Epist. 46.8.11 (392/93 AD), CSEL 54, pp. 338-41.

23 Bitton 2005, p. 74. 


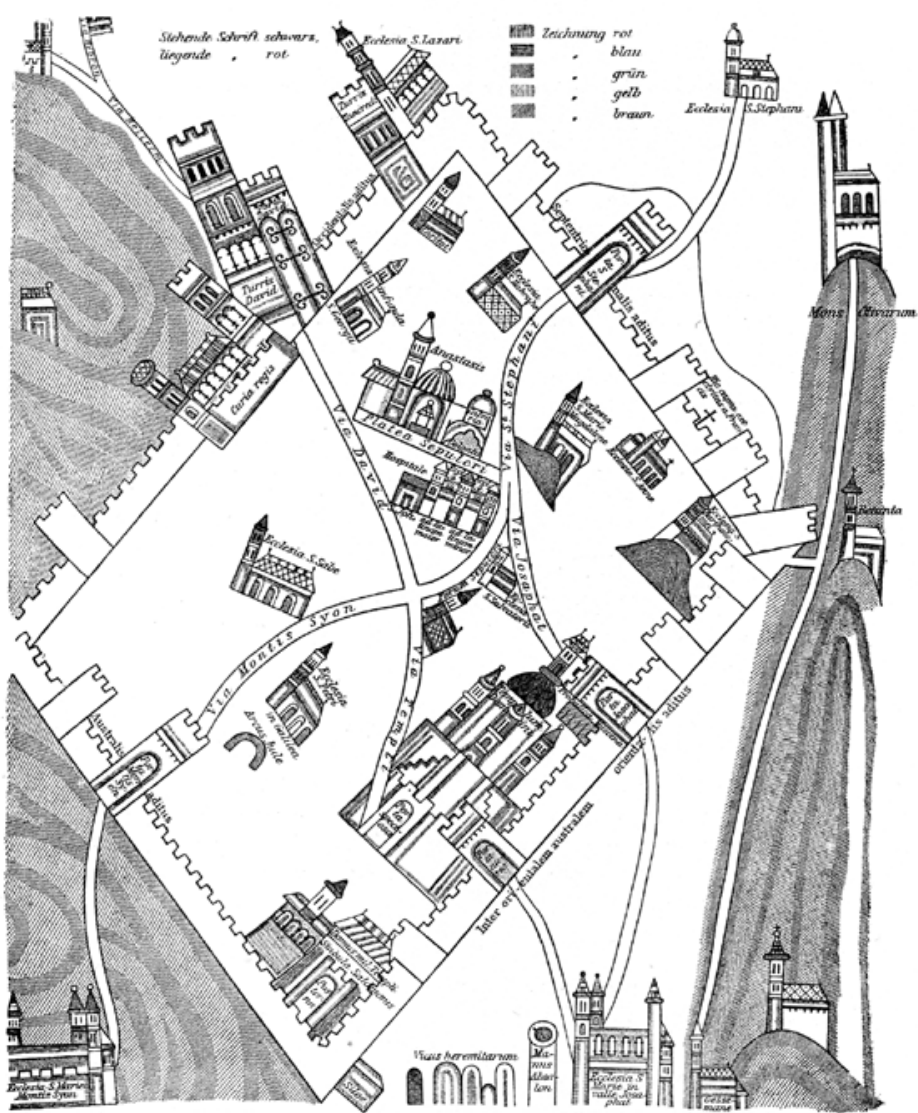

Plan von Jerusalem nach deru in Cambrai befindlichen Oriğinal c.1150 . (4i Orif̧malgrossse.)

FIGURE 6.2 Map of Jerusalem with city walls and churches (Bethlehem upper corner left). Design after ms. Cambrai, ca. 1150. FROM: R. RÖHRICHT, ZEITSCHRIFT DES DEUTSCHEN PALÄSTINA-VEREINS 14 (1891) TAV. 4.

\section{Jerusalem Hierotopy in Rome and the Diffusion of Cross Relics}

In this light, the decision to bring a particle of the 'sacred wood' to Rome and to make it the focus of an imperial foundation must have been a meaningful and ostentatious choice in the early phase indicated above. It is not known who took the initiative, but the idea can only have arisen in the context of the empire-wide imperial patronage for the Christian Church. The creation of a memoria of the Holy Cross, probably the first outside Jerusalem, must have aimed at adding a spiritual quality to the already existing eminence of Rome as the city of the apostles Peter and Paul and of numerous martyrs. Through it, 
the Roman Church was able to appropriate a key aspect of Jerusalem's rising identity as the unique Christian Sacred City. As noted above, the nomenclature Hierusalem of the Roman memoria, and maybe the arrangement of the Cross relic in a separate room behind the main apse, refer directly to the topographical dimension of the relationship with Jerusalem.

With this notion of the appropriation of Jerusalem that could be traced back to the emperor Constantine, the second founder of Christian Rome after the apostles, the Church of Rome might cherish the potential of demonstrating itself as a successor and substitute for the earthly Jerusalem. Hierotopy, the creation of sacred places, was an important instrument used by church leaders such as Pope Damasus (bishop of Rome 366-84) to establish Rome as the Christian Sacred City par excellence, at the same time that his colleague Cyril was working with similar intentions in Jerusalem. ${ }^{24}$ However, the presence of an early Cross relic in Santa Croce and the concomitant topographical notion of holiness associated with this church were not capitalized on systematically to the greatest extent during the following decades and centuries, as far as the scanty sources report it. Damasus set the tone in concentrating entirely on the Roman martyrs, without any reference to the Cross relic.

The story of the Finding by Helena was not linked to the Constantinian relic in Rome before the late Middle Ages. This is notwithstanding the popularity of the Finding legend on one hand, and on the other the high probability of some connection between Helena and the Sessorian palace complex, in which the Hierusalem memoria was created (Fig. 6.3). ${ }^{25}$ Epigraphical evidence suggests that the empress made use of the palace during her stays in Rome, the city where she died and was buried in 329 / 330 AD. About 500 AD the 'Sessorian' church was spontaneously mentioned as Basilica Heleniana. ${ }^{26}$ The editor of the Liber Pontificalis in the early sixth century refers to Helena as 'beata', implying her sainthood. ${ }^{27} \mathrm{He}$ also gives evidence of knowing the so called Judas Cyriacus version of the Cross Finding legend. ${ }^{28}$ Nevertheless, the same editor refrains from including Helena's name in the passage on the foundation of the Basilica Hierusalem and the donation of a Cross relic by her son Constantine. Obviously, he saw no reason to give the widely known legend of the Finding of the Cross a specific Roman twist.

\footnotetext{
$24 \quad$ For the term hierotopy see: Lidov 2006.

25 De Blaauw 1997, p. 6o; Brubaker 1997, pp. 57-69.

26 Gesta Xysti in LP (Duchesne 1886 1, p. 196 n. 75).

$27 \quad$ LP 34 C. 26.

28 LP 32 c. 2.
} 


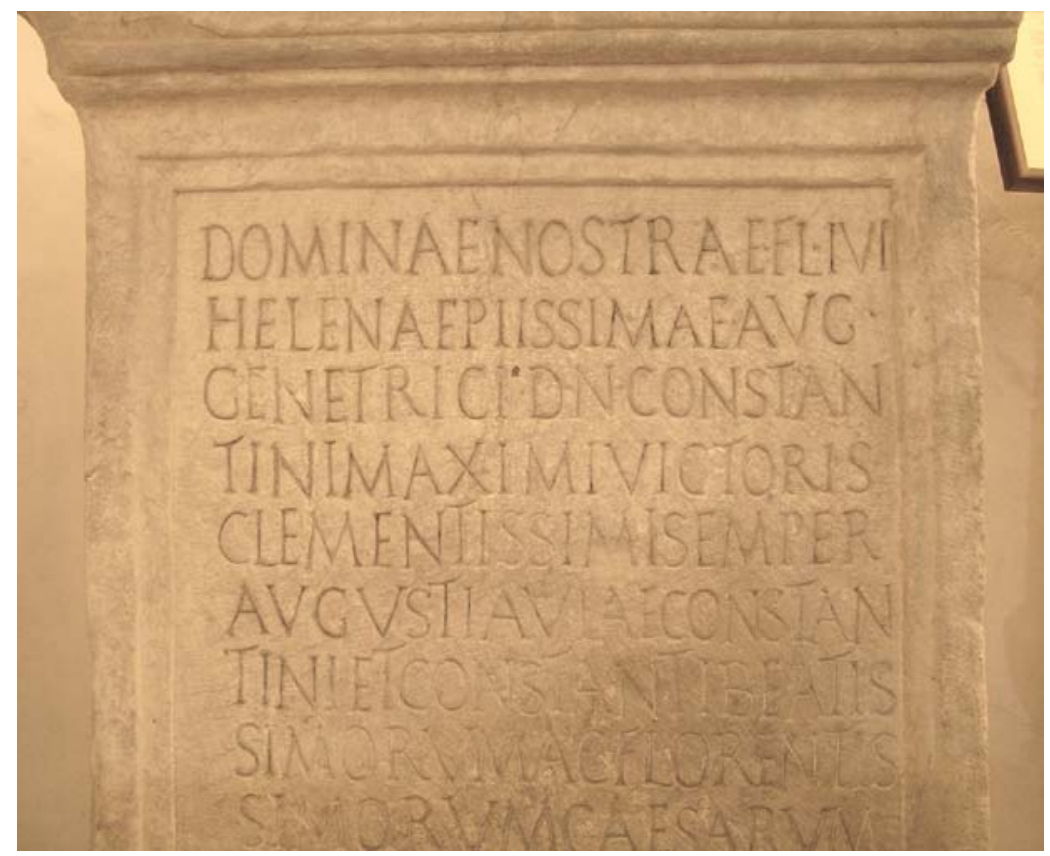

FIGURE 6.3 Rome, S. Croce in Gerusalemme, inscription referring to Helena from the Sessorian Palace, fifth century. PHOTO: SIBLE DE BLAAUW.

Meanwhile, the expansion of the cult of the Cross in the Christian world from the last quarter of the fourth century onwards had produced a number of places were Cross relics were kept and venerated. The earliest testimony after that of the Roman relic comes from Northern Africa, where in Tixter (Kherbet Oum el-Ahdam, modern Algeria) an inscription mentions relics kept in a Christian sacred building. ${ }^{29}$ ' Holy memorial. Part of the earth of promise where Christ was born, [...] of the apostles Peter and Paul [... of African martyrs] and part of the wood of the Cross'. It is clearly dated $359 .{ }^{30}$ Apart from the local saints, the items mentioned are striking. Rome was firm in not allowing the distribution of relics of its martyrs for many centuries. The items regarding Peter and Paul must have been secondary or contact relics, but even for this category, the mention is very early. Just as remarkable are the relics from the Holy Land, referring to the Nativity and the Crucifixion of Christ. Both Cross relics and earth or stone from holy places would become very common relics

29 Cooley 2012, pp. 246-48; Duval 1982 vol. 1, pp. 331-37.

30 The line regarding the Cross may have been added, but only slightly afterwards and in the same lettering: Duval 1982 vol. 1, pp. 331-37. 
in the future, but their existence at this date, in a rural place in the province of Mauretania is noteworthy. The inscription demonstrates that the growing awareness of the holiness of the sites of the Salvation was a widespread phenomenon in the Roman world of the third quarter of the fourth century.

The new capital of Constantinople was credited as having the most important Cross relics after the remnants preserved on Golgotha itself. The earliest version of the Helena Legend mentions the relic of Constantinople, sent by Helena to her son, but keeps silent on that of Rome. ${ }^{31}$ This silence on the other versions of the legend may be explained by the Eastern perspective of the legends, but, in the long run, this account will certainly have had its effect given the background of the rivalry between the two capitals. The sources from Constantinople, however, fail to provide an unequivocal view of the presence of significant Cross relics in the city. ${ }^{32}$ Obviously, no explicit cult of the Cross had developed in the Eastern capital since the alleged translation from Jerusalem. ${ }^{33}$ Only in the late sixth century, after the translation of another celebrated Cross relic from Apamea, did a popular tradition of veneration of the Cross begin to turn up in Constantinople. ${ }^{34}$ Meanwhile, the significance of Constantinople itself as a Sacred City had been emphasized by those Christian authors who criticized the obsession with pilgrimage to the Holy Land. The author of the Life of Daniel the Stylite around 500 AD, for example, encourages his readers with the words of the Byzantine saint himself to refrain from the journey to Jerusalem, but rather to go on local pilgrimage to the capital: with its tombs of martyrs and honour inspiring places 'you will see the Second Jerusalem there'.35 This qualification was certainly exaggerated, since it was exactly the lack of important martyr's tombs that was a tangible weakness of the New Rome compared to the Old. A systematic development of Constantinople as a centre of pilgrimage and a site of loca sancta seems only to have occurred in the Komnenian period (1081-1185) ${ }^{36}$

The diffusion of the wood of the Cross made the possession of Cross relics less exclusive and the claim to embody Jerusalem less imaginative. In Rome itself during the later fifth century, popes provided the baptisteries of the main basilicas, the Lateran and St Peter's, with special chapels containing Cross

$31 \quad$ Rufinus Aquileiensis, Historia Ecclesiastica 10.7 in: Eusebius Werke 2.2, 1908, p. 970.

32 For the improbability of a relic collection in Constantinople already under Constantine see: Wortley 2004.

33 Klein 2004, pp. 33-35.

34 Klein 2004, pp. 36-37.

35 Bitton 2005, p. 202.

36 Magdalino 2004, 26-27; Bozóky 2007, pp. 85-87, 94-106. For a different view see: Maraval 2002. 
relics mounted in gold and precious stones. ${ }^{37}$ Yet, the earliest relic in Rome could have been exploited just because of its early date and celebrated donor. Its fame, however, does not seem to have spread about outside Rome. Whereas the city became a principal destination for pilgrimage from the entire Christian world during the fourth century, the focus was exclusively on the tombs of the Apostles. ${ }^{38}$ The Cross relic is never mentioned by any external source. But there is also a virtual absence of local witnesses. Leo the Great (444-61), the first noteworthy theologian among the Roman bishops, highlights the significance of the Cross as the symbol of Christ's triumph and recognizes the value of Cross relics as testimonies of the Incarnation that may help to strengthen the faith, without ever referring to the prominent existence of such a relic in Rome itself. ${ }^{39}$ His later successor Gregory the Great (590-604) has a definite interest in the martyrs' tombs in Rome and in the phenomenon of relics. At the same time, he shares the critique of earlier authors on distant pilgrimages to the Holy Land, diverging openly from Jerome and his Roman followers. ${ }^{40}$ All the same, this opinion did not keep him from supporting institutions for pilgrims in Jerusalem and the Holy Land with money and goods. ${ }^{41}$ Ultimately, Gregory nourished a predominantly spiritual view of Jerusalem: as the place of God it can be in the soul of each individual in search for peace, wherever he or she is. ${ }^{42}$

Even if the interest in Rome for its connection with the Holy Land and its sacred topography may not have been consistent and enduringly intense, it appeared to be a lasting feature of the papal city and it survived Late Antiquity. Rome's second urban patriarchal church, Santa Maria Maggiore, bore the epithet ad praesepe from the seventh century onwards. The name implies the existence of a relic of Christ's manger from Bethlehem. Indeed, these relics are documented in Santa Maria Maggiore in later centuries, as well as a special chapel at the northern flank of the nave to shelter them. ${ }^{43}$ The first record of the name ad praesepe may not accidentally occur in the pontificate of Pope Theodore (642-49), himself born in Jerusalem. ${ }^{44}$ Its promotion occurred in a dramatically new political configuration. The Holy Land had been captured by the Arabs in 637 , so that the safety of the important testimonies of the

\footnotetext{
$37 \quad$ LP 46 c. 3; LP 53 c. 7; De Blaauw 1997, pp. 68-69.

38 Bardy 1949.

39 Leo Magnus, Tractatus 59.4.7 (444 AD), ed. 1973, pp. 354-59.

$40 \quad$ Bitton 2005, pp. 51-57.

41 Gregorius Magnus, Epist. 13.26, ed. CCL 140A, p. 1027; Maraval 1991, pp. 66-67.

42 Gregorius Magnus, Hom Ez. 1. 10.24, ed. CCL 142, p. 156; Maraval 1991, pp. 72-75.

43 De Blaauw 1994, pp. 400-01; Saxer 2001, pp. 70, 103-04.

44 LP 75 C. 2.
} 
Incarnation had become an urgent issue. ${ }^{45}$ Theodore interfered directly in aid of the continuation of the Christian presence in Jerusalem. During the next decades, the papacy showed its lasting interest in the Holy City and was even able to fill part of the power vacuum in Christian Jerusalem. ${ }^{46}$ In the inner Roman perspective, the parallels of the Roman Bethlehem with the Jerusalem of Santa Croce cannot be missed. Albeit chronologically distant in their origins, the creation of 'Bethlehem' may have strengthened and updated the older 'Jerusalem' and the other way around maybe the Cross memoria has helped to enhance the credibility of that of the Crib. The reception of this Holy Land topography in Rome is testified in an eleventh century ordo for the coronation of the Holy Roman emperors in Rome, in which the newly crowned emperor makes a miniature pilgrimage from the 'Bethlehem church' to the 'Jerusalem church. $^{47}$

\section{Iconographical Evocations of Jerusalem}

The representation of the Holy Land plays a remarkable role in the monumental iconographic programmes of Late Antique Roman churches. In one of the earliest preserved apse mosaics, of Santa Pudenziana (shortly after $400 \mathrm{AD}$ ), a representation of Jerusalem even constitutes one of the main iconographic components (Fig. 6.4). Behind the enthroned Christ in the midst of the college of apostles, a tall jewelled cross on a hilltop emerges against the backdrop of a panoramic cityscape with representative buildings.

The diverging interpretations of the Santa Pudenziana mosaic actually contribute to the perception of a multilayered meaning with levels of representation that largely do not exclude each other. ${ }^{48}$ Christ appears at the same time as King, Teacher, Judge and God. The composition of the mosaic with the central throne clearly refers to the actual liturgical situation in the apse during the Eucharist, where - on stational days - the Roman bishop would sit on the central cathedra and the higher clergy (the later cardinals) on the wall benches at both sides of the pope. The teaching function of Christ is directly mirrored in that of the pope underneath. This is also a representation of the Church,

\footnotetext{
45 Ó Carragáin 2005, p. 239.

46 Van Dijk 2001, pp. 324-27.

47 '[... coronatus vadit de ecclexia Bethleem ad ecclexiam Yerusalem', Ordo Coronationis Imperatoris 13.7, MGH Fontes iuris Germanici antiqui in usum scholarum 9, 1960, p. 35. This ritual is not referred to again in the later ordines.

48 Dassmann 1970 (still fundamental); Kühnel 1987, pp. 63-72.
} 


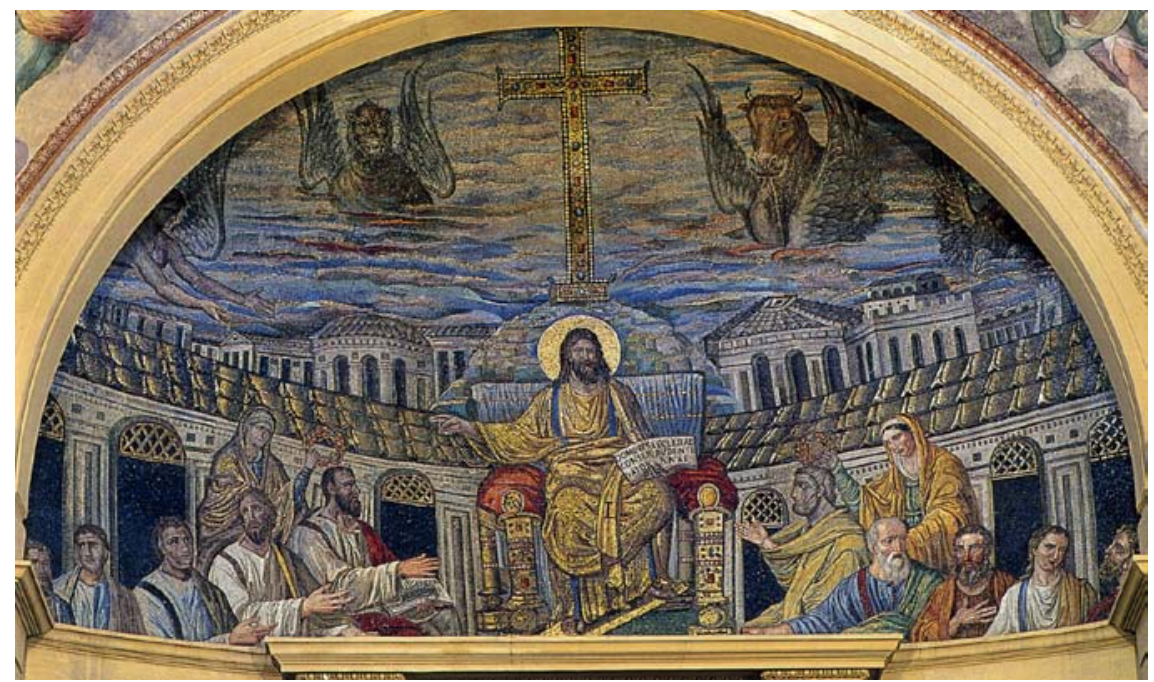

FIGURE 6.4

Rome, S. Pudenziana, apse mosaic, ca. 410. PHOTO: CENTRUM VOOR KUNSTHISTORISCHE DOCUMENTATIE, RADBOUD UNIVERSITY NIJMEGEN.

emphasized by the two women, who may symbolize the Jews and the Gentiles as the distinct groups constituting the Church. Christ is without doubt depicted in his divine being, harking back to iconographical features of the pagan gods. ${ }^{49}$ But every visitor to the church would also immediately recognize the imperial characteristics used to express the complex idea of a majestic GodMan. The women holding crowns actually take part in an imperial throning ceremonial. Simultaneously, the mosaic clearly has an eschatological perspective, in the Four Living Creatures from the Book of Revelation. The reflection of a terrestrial reality and the heavenly vision that are both present in the mosaic are connected by the cross and the city. The cross - preciously decorated with gems - rises on a hill cut back to bare stone, which is clearly a representation of Golgotha in Palestine. ${ }^{50}$ At the same time, the cross does not represent the moment of the Crucifixion but is in its glorified appearance a symbol of the Triumph of Christ. These terrestrial and heavenly layers of meaning must therefore also be present in the city panorama. The buildings behind the continuous porticus are rendered in such a particular way that they are most likely reproductions of actual monuments in earthly Jerusalem. They may include the Christian buildings Anastasis and Martyrium to the left, and the Imbomon

49 Mathews 1993, pp. 98-114.

$5^{0}$ On the Real Cross monument of Golgotha see: Heid 2001[a], pp. 169-242. 
and Eleona basilicas on the Mount of Olives to the right. ${ }^{51}$ This portrayal of the earthly, Christianized Jerusalem was the best formula for representing the heavenly city of New Jerusalem that was the focus of the eschatological message of the liturgy as well as of sacred iconography. ${ }^{52}$ The gemmed cross would return as the central motif of several Roman mosaics during the next centuries, for example in the added small apse in Santo Stefano Rotondo. The mosaic was installed by Pope Theodore (642-49) in a chapel that he created as the burial place for his father, originating from Jerusalem. ${ }^{53}$ Though the Jerusalem association of this cross may have been very concrete, since it may have represented the gemmed cross standing on Golgotha after the 'liberation' of Jerusalem from the Persians by the emperor Heraclius in 629, there is no topographical context, not even a hilltop. ${ }^{54}$

A more specific representation of Holy Land sites is again to be found in the fifth century, on the former apse arch of Santa Maria Maggiore (432-40 AD). The cycle dedicated to the Childhood and Second Coming of Christ includes the emblematic images of two cities as each other's counterparts in the lower zone of the arch. They are inscribed as Hierusalem (left) and Bethleem (right). Even though the compact formula and the jewelled walls might indicate otherwise, they are primarily the symbolic representations of the real cities in Palestine, with some of their characteristic buildings. ${ }^{55}$ The gems on the walls are clearly derived from the apocalyptic Jerusalem, but obviously transmitted to the earthly cities. (Bethlehem has no eschatological character.) The sheep coming from the cities stress their symbolic meaning for the Church for Jews and Gentiles respectively.

Due to the fragmentary survival of Early Christian monumental iconography and an almost complete vacuum of examples in the East, it is not possible to evaluate the surviving works in Rome in a comparative way. ${ }^{56}$ Yet, a pronounced topographical spotlight on the earthly Jerusalem is visible mainly in two works of the first half of the fifth century. The heavenly Jerusalem may

51 Pullan 1998 (with some debatable points regarding details); Heid 2001[a], 176-88; critical: Deckers 1988, pp. 326-30.

$5^{2} \quad$ Matthiae 1967, p. 61; Ó Carragáin 2005, pp. 232-33.

53 LP 75 c.1/ c. 4 (and note 1 by Duchesne 1886 1, p. 333); for Theodore's father's burial: Syll. Laureshamensis I, Duchesne 1886 1, p. 334 n. 9.

54 Ó Carragáin 2005, p. 234.

55 Gerhard Steigerwald, forthcoming article in Jahrbuch für Antike und Christentum 55 (2012); cf. Sahner 2009, p. 114.

56 I leave in abeyance Osborne 2008 on the seven candlesticks in the ss. Cosma e Damiano mosaic as possible allusion to the lost Temple treasure. 
have been less a focus than has often been suggested. ${ }^{57}$ Moreover, even in an eschatological context, the representation of Jerusalem may have exhibited recognizable features of the real city. The imagery of the triumphal Cross, on the other hand, was directly associated with the gemmed relic crosses in which the wood of the Holy Cross was preserved and venerated in real liturgy.

\section{Liturgical Evocations of Earthly Jerusalem}

In the Roman liturgical year three days were more or less focussed on the cult of the Cross. Good Friday belonged to the most ancient core of the liturgical year over the entire Christian world. The feast of the Finding of the Cross on May 3rd may have originated in Rome, whereas the feast of the Exaltation of the Cross was introduced in Rome from the East, most probably soon after the triumph of Heraclius over the Persians and the recovery of the Holy Cross at Golgotha. Cross relics played a role in the ceremonial on Good Friday and on the Exaltation. In the late seventh century, when these rituals were first described in Rome, relics of the True Cross had become relatively numerous, also in Rome itself, so that they do not necessarily represent an explicit relationship to Jerusalem. However, such a direct relationship does exist in some aspects of the feast as celebrated in Rome.

The Inventio Crucis on 3 May is a direct result of the Judas Cyriacus version of the Cross Finding legend, which mentions the discovery by Helena on the third day of May. ${ }^{58}$ The probable creation of this feast in Rome, outside the papal liturgy and at a relative early date - it was observed in the sixth century - is a remarkable testimony of a rare Western initiative in this context. One wonders whether this purposeful reception of the Eastern legend was a venture of the clergy of the Sessorian basilica, in an attempt to call attention to the relic and to the story that gave her its name, Hierusalem.

The introduction of the Exaltatio sanctae Crucis feast was stimulated by topical events in Jerusalem in 629-31. The day of 14 September was the traditional Dedication feast of the Holy Sepulchre church in Jerusalem, which became a celebration of Christian triumph after the defeat of the Persians and the restoration of the Cross memorial on Golgotha. In Rome, its commemoration was combined with the veneration of a 'lifegiving' relic of the Holy

$57 \quad$ Thraede 1996, cc. 757-60.

$5^{8}$ De Blaauw 1997, pp. 70-72 (with further literature). 
Cross. ${ }^{59}$ This is testified for St Peter's, but probably was also in use in other churches that had a precious Cross relic in their possession. ${ }^{60}$ Ultimately, under the Syrian Pope Sergius I (687-701) the feast was part of the papal liturgical system. The author of Sergius' life in the Liber Pontificalis gives it a special profile by means of a semi-miraculous story of the 'discovery' of a forgotten but very precious relic cross in a 'dark corner' of St Peter's. ${ }^{61}$ On opening a silver casket and removing a silk cushion that was in it, the Pope found a metal cross decorated with precious stones. After removing the four plates in which the jewels were embedded he discovered a large and indescribable portion of the saving wood of the Lord's Cross'. This relic was obviously judged to have an extraordinary value, since it was transferred to the papal residence of the Lateran and exposed in the Lateran basilica each year on 14 September, to be kissed and worshipped by the people. It is the oldest known Cross relic in Rome that can be traced physically, with a fair amount of probability, until modern times. The gemmed cross containing the sacred wood with a balmfilled cavity in its centre was discovered in the altar of the Lateran palace chapel in the early twentieth century in a cruciform silver container from the Carolingian period. ${ }^{62}$ The central role given to this relic in the papal liturgy of the Exaltatio from the late seventh century onwards proves that it was considered the major Cross relic in Rome and the most direct representative of the relics that were kept on Golgotha itself, meanwhile under Muslim rule.

The liturgy of Good Friday certainly was the oldest Jerusalem-related rite in Rome. The earliest lists of papal stations, rooting in the later fifth century, mention the basilica Hierusalem as the place for the celebration on the day of Christ's death. ${ }^{63}$ The role of the basilica's Cross relic, however, is unclear. Only after 700 does the earliest preserved description of the rite mentions a solemn veneration of the Cross by pope and people at the altar of Santa Croce, but this was astonishingly not the Constantinian relic. The object of veneration was brought in a penitential procession from the Lateran, and was in all probability identical with the relic cross discovered in St Peter's and since then secured in the palace chapel of the Lateran. The description of the Cross in the ordo for

59 On the introduction of the feast in the West: Van Tongeren 1998, 41-77; cf. Constantinople: Klein 2004, pp. 40-43.

60 Van Tongeren 1998, pp. 52-59; Ó Carragáin 2005, pp. 189-92; De Blaauw 1994, pp. 197-98.

$61 \quad$ LP 86 c. 10.

62 Thunø 2002, pp. 21-22. The gemmed cross itself is now lost, but photographs and descriptions exist.

63 De Blaauw 1997, pp. 71-72; De Blaauw 1994, 188-89. The suggestion of Grisar 1925, pp. 4-6, that the Roman stational organization was based on that of Jerusalem has proven to be untenable in the light of later research. 
the ritual corresponds perfectly to the other information: it was carried in a gold casing with gems, the wood of the Cross itself was covered with gold and gems and had a cavity with odoriferous balm. ${ }^{64}$

Accordingly, about $700 \mathrm{AD}$ the gemmed cross from St Peter's/ the Lateran palace had been able to surpass other well known Cross relics in Rome, particularly those of the Vatican and Lateran baptisteries and that of Santa Croce. The reason for this remarkable turn, even in the primeval rite of Good Friday, is unknown, but it definitely was an infringement of the prestige of the relic tradition of Santa Croce. The most plausible explanation is, that the Constantinian relic in its precious casing had not survived the sackings of Rome in the fifth century. Notwithstanding the loss of an object, the identification of the Constantinian memoria with Jerusalem was rooted deeply enough in Roman soil to warrant that the station of papal liturgy on the days of the liturgical year which had the strongest associations with Jerusalem be held in Santa Croce: Good Friday and the Sunday of Lent when the psalm 'Laetare Hierusalem' was sung as the Introit. Meanwhile, the role of the palace as a treasury for the most precious relics has a parallel in the imperial palace of Constantinople, from where a Cross relic was carried forth in processions. ${ }^{65}$

Perhaps the ritual significance of Cross relics had not been essential in Rome in the preceding centuries. The unmistakable boost in the cult of the Cross during the seventh century may have been energized by developments in the East, above all by the vicissitudes of Jerusalem, that saw the extinction of Byzantine Christian rule in favour of Persian and finally of Arab power. The development of Roman rituals in this period shows at any rate a special susceptibility for the traditions of Jerusalem, a phenomenon likewise visible in Constantinople. ${ }^{66}$ The Good Friday procession from the Lateran to Santa Croce had clearly mimetic features in relation to the procession of bishop and pilgrims in Jerusalem to venerate the Cross at Golgotha, including its associations with the Passover of Exodus and its eschatological perspective of journeying towards the heavenly Jerusalem. ${ }^{67}$ The fact that not the pope, but the Cross relic was the protagonist of the procession, and the barefoot walking of all participants as a penitential gesture, made this procession to $\mathrm{S}$. Croce into a

\footnotetext{
$64 \quad$ OR XXIII 11, Andrieu 3 (1974), p. 271.

65 Klein 2004, pp. 36-37; Flusin 2004, pp. 69-70 (11th century); Bacci 2003; Lidov 2012; Bozóky 2007, pp. 106-18 (views the imperial relic collection in Constantinople as the model for several imitations in the West. This is debatable in the light of the Lateran tradition).

66 Klein 2004, pp. 41-43.

67 OR XXIII 9-22, Andrieu 3 (1974), pp. 270-72.
} 
symbolic pilgrimage to Golgotha. ${ }^{68}$ Even if Santa Croce no longer contributed a relic, its topographical association with the city of the Salvation could obviously still work in an effective way. The rite of veneration itself consisted of the opening of the reliquary casing on an altar and the exposition of the relic cross contained in it so that it could be kissed by the clergy and faithful. This was a century old tradition, practised in Jerusalem already in the late fourth century. ${ }^{69}$ The interaction of cult traditions between Jerusalem, Rome and Constantinople is obvious, but hardly traceable in its exact patterns of causes and effects, particularly before the seventh century. This is precisely why it is important to underline the bare facts of the Jerusalem association in Rome in the fourth century and the development of the cult of the Cross in the fifth century under the aegis of the popes.

\section{Diachronic Perspectives}

The attention to the historical sites of the Salvation in Early Christian Rome had no counterpart in a direct interest for the Jewish history of the Holy Land. On the other hand, neither is there any indication of a conscious strategy to deny or outdo the Jewish discourse on the Land of Israel. ${ }^{70}$ Any local interest in the sacred vessels of the Herodian Temple, installed by Vespasian in Rome as trophies, is lacking before the eleventh century. ${ }^{71} \mathrm{~A}$ general Christian attention to the biblical temple and its cult was slowly developing and resulted in a more consistent corpus of exegetical reflection and symbolic interpretation only after the treatises on the Tabernacle and the Temple by the Venerable Bede in distant Britain in the decades around $700 .{ }^{72}$ Notwithstanding the strong metaphorical concept of these works, they enhanced and stimulated knowledge of the historical temples of Jerusalem. ${ }^{73}$

Direct reflections of the Jerusalem Temple are found in Rome from the eleventh century onwards. Then, the papal chapel of St Lawrence in the Lateran palace started to be entitled Sancta Sanctorum. The expression sancta sanctorum was already known for the relic collection in a church altar since the early

\footnotetext{
68 Ó Carragáin 2005, pp. 148-150, 183-201.

69 Egeria 37. 1, Itineraria 1965, pp. 80-81; cf. Klein 2004, pp. 43-44.

70 Cf. Boustan 2008.

71 Boustan 2008, pp. 338, 358-59, 368.

72 O'Reilly 1995, pp. xvii-xviii.

73 The Temple as an object of emulation in the Early Christian tradition: Ousterhout 1990.
} 
fifth century. ${ }^{74}$ Nonetheless, its application for a spatial entity may indicate a strengthening of its original reference to the Holy of Holies in the Temple of Jerusalem. The collection of relics from the Holy Land and the Life of Christ in the altars of this chapel originates in the seventh or eighth centuries. ${ }^{75}$ Apart from the eminent Cross relic, the collection also contained geographical memories from the Holy Land in the form of stones and soil from the sacred sites, a genre going back likewise to the fourth century, witness the inscription from Tixter. In a recent study, Galland counts six written labels for relics from various biblical places, and several tens for relics from geographically indicated places related to the Life of Christ, almost all of them paleographically dated in the seventh or eighth century. This bears witness to a (first) inventory of the relic collection, which may itself have existed earlier. ${ }^{76}$ A twelfth century author brings to mind that the famous icon of the Saviour in the palace chapel, considered as not having been painted by human hands, had been brought to Rome by Titus and Vespasian. ${ }^{77}$

The association of the Lateran basilica with the Temple of Jerusalem in the High Middle Ages has been studied intensely during the last decades. ${ }^{78}$ From the tenth century onwards, the Temple allusion was obviously one of the means to distinguish the papal cathedral vis-à-vis the Vatican basilica with the tomb of Peter. Soon, the pretention of being the successor of the biblical Temple took on material features, with the claim that the basilica housed the sacred vessels of the Temple as relics in its high altar. ${ }^{79}$ This tradition has always been controversial in Rome itself, not in the least due to obvious historical improbabilities. The first author of the Description of the Lateran Church, a treatise originating in the later 11th century, attributes all the relics from the Temple purportedly kept in the basilica not to Titus and Vespasian, but to Helena, who would have brought them with her from Jerusalem to Rome, on behalf of her son Constantine. ${ }^{80}$ The successive versions of the Description during the twelfth century show how the process of uncovering the history of the Lateran basilica was verified using historical and legendary material, the main ingredients of which were Constantine, Helena and the Jerusalem Temple.

\footnotetext{
$74 \quad$ Nussbaum 1959, pp. 242-43.

75 Galland 2004, pp. 87-89.

76 Galland 2004, catalogue, pp. 93-144.

77 Nicolaus Maniacutius, quoted by Longo 2012, p. 133 .

78 Herklotz 2000 (new edition of earlier studies), here esp. pp. 170-80; De Blaauw 1990; some more recent studies are referred to in the following notes.

79 DLE, pp. 335-42; further references in: De Blaauw 1994, pp. 233-46.

$80 \quad$ DLE, cf. pp. 335 and 341.
} 


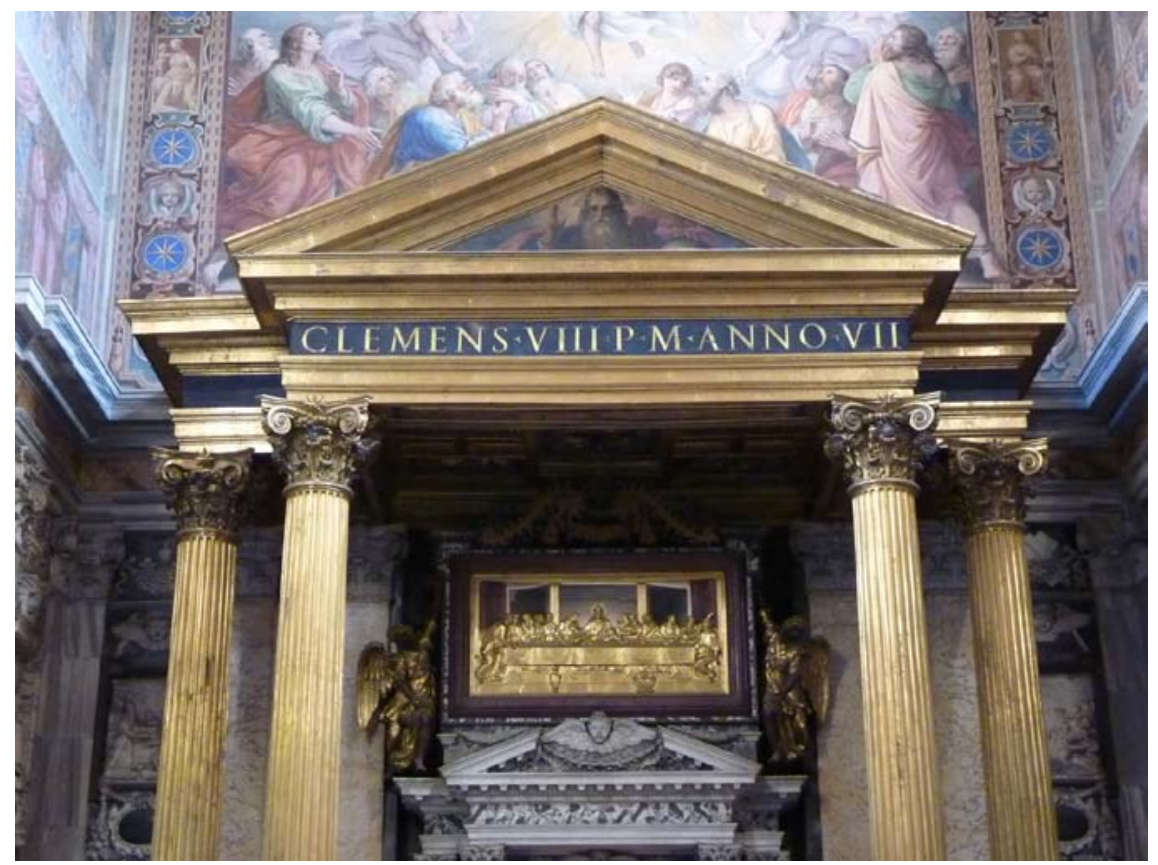

FIGURE 6.5 Rome, S. Giovanni in Laterano, classical bronze columns in the Altar of the Blessed Sacrament, 1600 , with original capital to the left. PнотO: SIBLE DE BLAAUW.

Another tradition claimed the singular bronze columns from imperial times, standing in front of the Lateran high altar, as coming from Jerusalem as well (Fig. 6.5). A solemn late thirteenth century inscription refers to the bronze columns as 'brought from Jerusalem to Rome by Titus and Vespasian'. ${ }^{81}$ More than a century earlier, the Jewish author Benjamin of Tudela had identified them as 'the handiwork of King Solomon' from the First Temple. ${ }^{82}$ From the sweat said to run down from the columns each year on the anniversary of the destruction of the Temple by the Romans, it is clear that the local Roman-Jewish community truly believed that these were relics of the authentic Temple, present in Rome.

Notoriously, pro-Lateran authors in the Reform period of the Church developed the concept of the real Jerusalem in Rome:Jerusalem, with the pope as its high priest, was now in Rome, and had taken over the relevance of the old Je-

$81 \quad$ Nilgen 1977, pp. 21-24 ('de Herusolima ad Urbem').

$82 \quad$ Champagne and Boustan 2011, pp. 477-81. 
rusalem in an eschatological perspective. ${ }^{83}$ Just as clear, however, is that this concept was nourished only in a limited circle and for a limited time: it was not decisive to the ideology of papal authority and had obviously already lost its vital force in the course of the twelfth century. In the polemics between the Lateran and Vatican canons, those of the Vatican took care to accuse their Lateran brothers of being 'iudeaeos et moysistas' serving a 'synagogue', deliberately avoiding the identification of the Lateran basilica with the Temple of Jerusalem. ${ }^{84}$ Notwithstanding some propagandistic turns, the medieval Lateran complex cannot plainly be read as a lieu de mémoire of the Temple and the Holy Land. Ingo Herklotz has demonstrated that the combination of reminiscences, in which Roman antiquity as well as the first Christian emperor, Constantine, play a prominent role, was ultimately focussed on Christ and above all on the pope as Christ's representative on earth, as high priest and as imperial ruler. 85

Since the beginning of the Crusades, material memorabilia from the Holy Land and the earthly Jerusalem spread all over Western Europe in a never equalled density. After the Fall of Constantinople in 1204, the dispersal of the Holy Land treasures collected over centuries in the Eastern Christian capital augmented the Western relic resources with a last quantitative and qualitative inundation. ${ }^{86}$ Since then, at the latest, the material mementoes of Jerusalem in Rome lost their relative exclusivity. Certainly, the acquisition of the famous Column of the Flagellation from the imperial palace in Constantinople by the Roman cardinal Giovanni Colonna in 1223, was a major catch. ${ }^{87}$ Nevertheless, the relic, placed in the Zeno-chapel of the cardinal's titular church of S. Prassede, never attained the prestige and popularity of Christ's Crown of Thorns, brought from Constantinople to Paris via Venice in 1238-1239 as a trophy by King Louis IX. Other relics came directly from the Holy Land to Rome, in order to rescue them for the possible threat of the Arab re-conquerors. A significant case was the 're-burial' of St Jerome, whose remains were translated from his tomb in the Nativity church in Bethlehem to Santa Maria Maggiore. ${ }^{88}$ An altar with his relics was set up in front of the entrance to the Praesepe-chapel in the course of the thirteenth century, so that the direct connection of the church father to the site of the Nativity of Christ was suggested as continuing. Thus,

\footnotetext{
83 Cf. Longo 2012, pp. 134-36.

$84 \quad$ Longo 2012, p. 126.

85 Herklotz 2000, pp. 10-14.

86 Byzance et les reliques 2004, pp. 91-105, 183-90, 238-48.

$87 \quad$ Vannuttelli 1896.

88 Saxer 2001, pp. 343-66; De Blaauw 1994, pp. 408-09.
} 
Rome not only confirmed its association with Bethlehem, but also fetched back one of the most important teachers of the faith who had once left the city in favour of the Holy Land. The retrospective consideration that no remains of the saint have ever been discovered in the Roman basilica only corroborates the frequent experience of scholars that the spiritual intention of the story is more important than the purported facts. ${ }^{89}$

After the definite loss of the Latin territories in the Holy Land, the interest in the real city seems to have given way to a more spiritual concept of Jerusalem. The Jubilee Years promulgated by the popes from 1300 onwards made Rome into a full successor of Jerusalem for the pilgrims, substituting for it even in being the 'navel of the world' ${ }^{90}$ The links with old Jerusalem tended to become more symbolic, as part of a general process of universalization and mediation in late medieval piety ${ }^{91}$.

Meanwhile, ancient associations with Jerusalem in the Roman sacred landscape were retained and sometimes were revitalized. In the Lateran palace, new testimonies of the Holy sites popped up, notably the mensura Christi and the Holy Stairs. In the thirteenth century, the regular entrance steps of the medieval Lateran palace were said to be the steps that had led up to the praetorium of Pontius Pilate in Jerusalem. ${ }^{92}$ It is an interesting example of a long existing functional object that was provided gradually with a supplementary layer of significance as a relic, in this case of Christ's Passion. ${ }^{93}$ The same is true for three beautiful marble portals in the Lateran Aula of the Councils, said to be from Pilate's palace. ${ }^{94}$ The mensura Christi, four columns in the same large palace aula were believed in the fifteenth century to establish the corporal height of the Lord (Fig. 6.6). The stone tablet on which the soldiers played dice for the robe of Christ at his crucifixion was shown here as well..$^{95}$ Authors report the persistent, but unplausible tradition that these relics from Jerusalem were brought to Rome in the booty of Titus. Only later in the sixteenth century, was their presence in Rome connected to the pilgrimage of the pious empress Helena. ${ }^{96}$ By then, comparable relics had also appeared in secondary churches. For example, the stone on which Abraham intended to sacrifice Isaac and

89 On the archaeological search after St Jerome's relics in S. Maria Maggiore see: De Blaauw 1994, pp. 378-79.

$90 \quad$ Caputano 2005, pp. 354-57.

$91 \quad$ Wolf 1998, p. 427.

92 Horsch 2003.

93 D’Onofrio 1974, pp. 104-10.

94 D’Onofrio 1974, pp. 104-10.

95 Ginzburg 1982, pp. 68-70.

96 D’Onofrio 1974, pp. 107-08. 


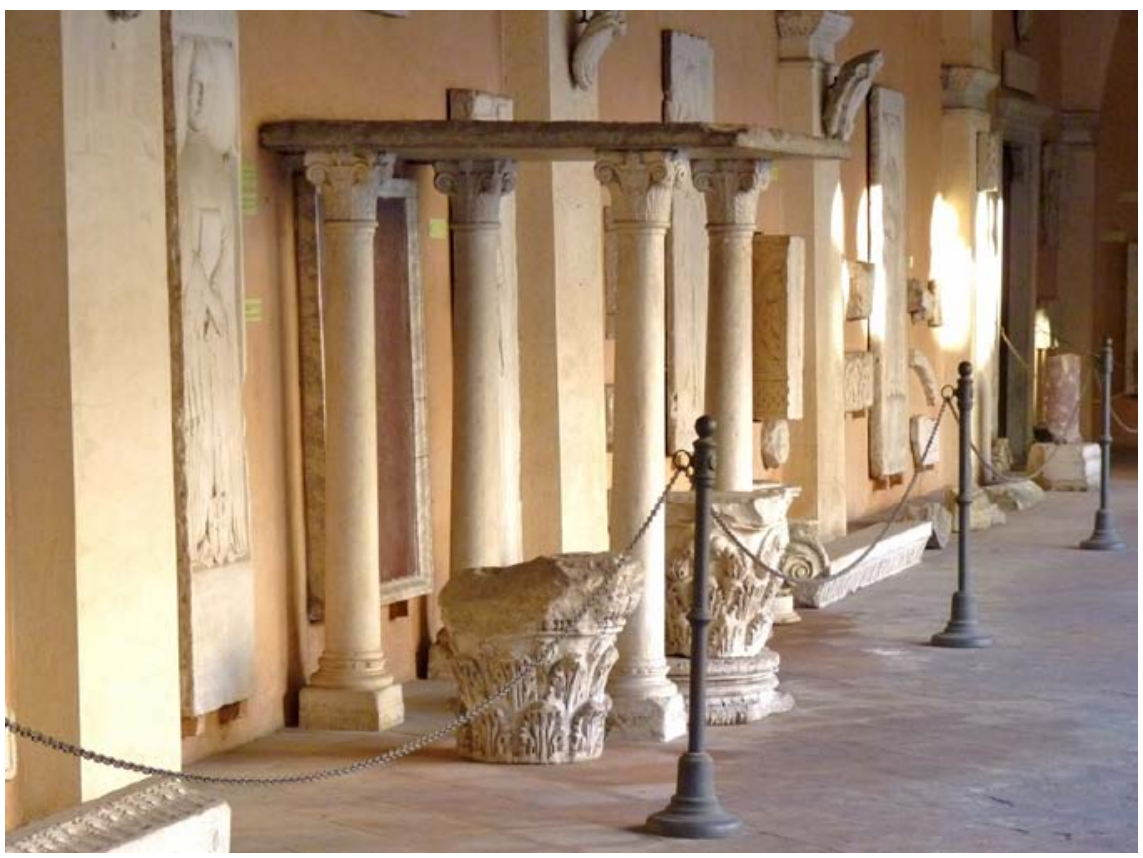

FIGURE 6.6 Rome, S. Giovanni in Laterano, cloisters, columns and marble stone from the Aula Concilii in the ancient Lateran Palace, constituting the Mensura Christi. PHOTO: SIBLE DE BLAAUW.

the altar on which Jesus was presented in the Temple of Jerusalem forty days after his birth, were preserved in an obscure church between the Tiber and St Peter's (now in the Church of the Frisians, ss. Michele e Magno). ${ }^{97}$

Certainly not by chance did the Vatican basilica appropriate an older tradition from the Lateran basilica by identifying the twisted vine-scroll columns in front of the high altar as spoils from the Temple of Solomon. The association of these exceptional spoils donated by Constantine with the Jerusalem Temple would find a successful reception in the Temple iconography from the fifteenth century onwards. ${ }^{98}$ At the same time, the Lateran had lost its Temple obsession, and had turned to the more solid Roman tradition of the veneration of the apostles Peter and Paul, whose alleged head relics were installed in the monumental ciborium of the high altar in 1370 circa. ${ }^{99}$

97 Tradition appearing in S. Giacomo a Scossacavalli in the sixteenth century: Grisar 1899, pp. $576-77$.

$98 \quad$ Danesi Squarzina 1991.

99 Mondini 2011. 
To return at last to the starting point of Jerusalem in Rome: during the Middle Ages the Church of S. Croce in Gerusalemme did not project a strong profile as the oldest Christological site related to Jerusalem in Rome. The titulus, the panel with inscription which was hung on Christ's Cross according to the Gospels, seems to have been the most prominent relic and was enclosed high in a wall niche of the new triumphal arch in the twelfth century. ${ }^{100}$ Peter Cornelius Claussen suggests convincingly that the singular marble decoration of the twelfth century bell tower, consisting of a double cross inserted in the front wall, is a medieval reference to the cult of the Holy Cross in this church. ${ }^{101}$ However, it is only in the course of the fifteenth century, that a more overt focus on the basilica's particular identity becomes discernable. The first Roman source linking Helena explicitly with the founding of S. Croce is Flavio Biondo about $1445 .{ }^{102}$ After the 'rediscovery' of the titulus relic in 1492 , not accidentally in the same year as the final defeat of Muslim rule in Spain, the Spanish cardinal priests of the basilica launched a grand scale revival of the cult of the Cross, including the veneration of Helena as founder of the basilica. The vault of the apse and the chapel of St Helena received new decorations celebrating the Holy Cross, its invention and exaltation. ${ }^{103} \mathrm{~A}$ long inscription combined several legendary traditions regarding the church, its relics and founders. Pilgrims now visited the chapel hearing that is was Helena's bedroom and that its pavement was laid on earth from Golgotha, brought along by the empress to her Roman palace. ${ }^{104}$

\section{Concluding Remarks}

There has never been a comprehensive and lasting concept of Jerusalem in Rome, neither on a devotional and liturgical level, nor as a coherent ideology. There are no traces of the creation of a 'sacred landscape' according to a 'topographical blueprint of the Holy Land' that would transform Rome into a 'New Jerusalem'. ${ }^{105}$ Yet, the materials for a direct line of meaning-transfer from

100 Claussen 2002, pp. 431-32.

101 Claussen 2002, pp. 427-30.

102 De Blaauw 1997, p. 66.

103 Gill 1995 .

104 Gerusalemme a Roma 2012, passim.

105 Sahner, p. 103. The problem of Sahners article is, apart from the errors in the use of sources and archaeological evidence, the underlying presupposition that Jerusalem was generally accepted as a model that had to be imitated or even to be reproduced as a 'blueprint'. There is hardly any evidence for this premise. 
Jerusalem to Rome were provided at a remarkably early date. 'Potentials' is the best term for them, used in a similar manner by Ousterhout when speaking on medieval Italian cities. He observes a 'wide range of potentials' with added associations 'that could transcend physical forms'. ${ }^{106}$ In the case of Rome, these possible capacities may have been stronger and more concrete than in other Italian cities, not at least due to the early origins of the relic traditions and their topographical associations. From Constantine onwards, this Jerusalem subtext could be activated and was activated at relevant moments in relevant places. The early cult of the Cross in the fourth and fifth centuries, as well as the Temple associations in the eleventh and twelfth centuries are the most specific Roman phenomena. It may seem astonishing that they were not exploited in a more intense and consistent way. The reason is, however, self-evident enough. The city of Peter and Paul did not need Jerusalem. In his 1868 treatise on the holy sites of the Jerusalem Temple and the Grotto of the Nativity, Domenico Bartolini, canon of the Lateran basilica and later a cardinal of the Holy Roman Church, deals extensively with the history of the locations in Palestine, but does not hit upon the idea of any allusion to the topographical traditions of the holy sites and the primeval Christological relics in Rome. ${ }^{107}$ Even with his genuine interest in Jerusalem, the nineteenth-century prelate cannot veil the long tradition of Roman superiority toward the Holy Land. Even Jerome came back to Rome.

\section{Bibliography}

Andrieu, Michel, Les ordines romani du haut moyen-âge, 5 vols, Leuven 1931-61.

Bacci, Michele, 'Relics of the Pharos Chapel: A View from the Latin West' in: Bocmoчнохристианские реликвии/Eastern Christian Relics, ed. by M. Lidov, Moscow 2003, pp. 234-48.

Bardy, Gustave, 'Pèlerinages à Rome vers la fin du Ive siècle', Analecta Bollandiana 67 (1949), pp. 224-35.

Bartolini, Domenico, Sull'antico tempio di Salomone in Gerusalemme, sua pianta ed avanzi e Sull'antica grotta del presepio di N.S. Gesù Cristo in Betlemme, soprastante basilica costantiniana ed altri luoghi storici annessi, Ph. D. diss., Rome and Turin 1868.

Bitton-Ashkelony, Brouria, Encountering the Sacred:The Debate on Christian Pilgrimage in Late Antiquity, Transformation of the Classical Heritage 38, Berkeley 2005.

106 Ousterhout 1998, p. 404.

107 Bartolini 1868. 
De Blaauw, Sible, 'The Solitary Celebration of the Supreme Pontiff. The Lateran Basilica as the New Temple in the Medieval Liturgy of Maundy Thursday' in: Omnes circumadstantes. Contributions Towards a History of the Role of the People in the Liturgy: Presented to Herman Wegman, ed. by Ch. Caspers and M. Schneiders, Kampen 1990, pp. $120-43$.

- Cultus et decor. Liturgia e architettura nella Roma tardoantica e medievale: Basilica Salvatoris, Sanctae Mariae, Sancti Petri, Studi e testi 355-56, 2 vols, Vatican City 1994.

—_ ' 'Jerusalem in Rome and the Cult of the Cross' in: Pratum Romanum. Richard Krautheimer zum 10o. Geburtstag, ed. by R. Colella et al., Wiesbaden 1997, pp. $55^{-73}$.

Boustan, Ra'anan Shaul, 'The Spoils of the Jerusalem Temple at Rome and Constantinople: Jewish Counter-Geography in a Christianizing Empire' in: Antiquity in Antiquity: Jewish and Christian Pasts in the Greco-Roman World, ed. by Gregg Gardner and Kevin L. Osterloh, Tübingen 2008, pp. 327-72.

Bozóky, Edina, La politique des reliques de Constantin à Saint Louis. Protection collective et légitimation du pouvoir, Paris 2007.

Brandenburg, Hugo, Die frühchristlichen Kirchen Roms vom 4. bis zum 7. Jahrhundert. Der Beginn der abenländischen Kirchenbaukunst, Regensburg 2004.

Brubaker, Leslie, 'Memories of Helena: Patterns in Imperial Female Matronage in the Fourth and Fifth Centuries' in: Women, Men, and Eunuchs. Gender in Byzantium, ed. by Liz James, London 1997, pp. 52-75.

Byzance et les reliques du Christ. xxe Congrès International des Études Byzantines, 19-25 août 2001, ed. by Jannic Durand and Bernard Flusin, Paris 2004.

Caputano, Claudio, "Facta est Romana ecclesia nova Ierusalem": città terrena e città celeste nella visione di Gioacchino da Fiore' in:Fra Roma e Gerusalemme nel Medioevo vol. 3, ed. by Massimo Oldoni, Salerno 2005, pp. 337-58.

Champagne, Marie Thérèse and Ra'anan Shaul Boustan, 'Walking in the Shadows of the Past: The Jewish Experience of Rome in the Twelfth Century', Medieval Encounters [Medieval Jewish, Christian and Muslim Culture Encounters in Confluence and Dialogue] 17 (2011), pp. 464-94.

Claussen, Peter Cornelius, Die Kirchen der Stadt Rom im Mittelalter 1050-1300 A-F, Corpus Cosmatorum II, 1, Stuttgart 2002.

Cooley, Alison E, The Cambridge Manual of Latin Epigraphy, Cambridge 2012.

Danesi Squarzina, Silvia, 'La Sistina di Sisto IV e l'eredità del pensiero religioso medievale' in: Silvia Danesi Squarzina, Ricerche sul'4oo a Roma. Pittura e architettura, Rome 1991, pp. 215-49.

Dassmann, Ernst, 'Das Apsismosaik von S. Pudentiana in Rom: philosophische, imperiale und theologische Aspekte in einem Christusbild am Beginn des 5. Jahrhunderts', 
Römische Quartalschrift für christliche Altertumskunde und Kirchengeschichte 65 (1970), pp. 67-81.

Deckers, Johannes G., 'Tradition und Adaption: Bemerkungen zur Darstellung der christlichen Stadt', Römische Mitteilungen 95 (1988), pp. 303-82.

DLE: Descriptio Lateranensis ecclesiae: R. Valentini - G. Zucchetti, Codice topografico della città di Roma, 4 vols, Rome 1940-53, vol. 3 (1946), pp. 319-73.

D’Onofrio, Cesare, Scalinate di Roma, Rome 1974.

Drijvers, J.W., Helena Augusta. The Mother of Constantine the Great and the Legend of her Finding of the True Cross, Leiden 1991.

Drijvers, H.J.W and J.W. Drijvers, The Finding of the True Cross: The Judas Kyriakos Legend in Syriac. Introduction, Text and Translation, Leiden 1997.

Duval, Yvette, Loca sanctorum Africæ. Le culte des martyrs en Afrique, du 4e au 7e siècle, 2 vols, Rome 1982.

Elsner, Jàs, 'The Itinerarium Burdigalense: Politics and Salvation in the Geography of Constantine's Empire', The Journal of Roman Studies 90 (2000), pp. 181-95.

Eusebius Werke 2: Die Kirchengeschichte, ed. by Eduard Schwartz and Theodor Mommsen, 3 vols, Leipzig 1903-09.

Galland, Bruno, Les authentiques de reliques du Sancta Sanctorum, Studi e testi 421, Vatican City 2004.

Gerusalemme a Roma. La Basilica di Santa Croce e le reliquie della Passione, ed. by Roberto Cassanelli and Emilia Stolfi, Milan 2012.

Gill, Meredith J., 'Antoniazzo Romano and the Recovery of Jerusalem in Late FifteenthCentury Rome', Storia dell'arte 83 (1995), pp. 28-47.

Ginzburg, Carlo, The Enigma of Piero. Piero della Francesca, the Baptism, the Arezzo Cycle, the Flagellation [transl. from Italian 1981], London 1985.

Grisar, Hartmann, 'Antiche basiliche di Roma imitanti i santuarii di Gerusalemme e Betlemme' in: idem, Analecta Romana, Rome 1899, pp. 555-94.

_- Das Missale im Lichterömischer Stadtgeschichte: Stationen, Perikopen, Gebräuche, Freiburg im Breisgau 1925.

Heid, Stefan, Kreuz, Jerusalem, Kosmos. Aspekte frühchristlicher Staurologie, Jahrbuch für Antike und Christentum. Ergänzungsband 31, Münster 2001[a].

__ ' 'Die gute Absicht im Schweigen Eusebs über die Kreuzauffindung', Römische Quartalschrift 96 (2001[b]), pp. 37-56.

Herklotz, Ingo, Gli eredi di Costantino. Il papato, il Laterano e la propaganda visiva nel XII secolo, Rome 2000.

Horsch, Nadja, 'Die Scala Santa im mittelalterlichen Lateranpalast: eine neue Lektüre der Quellen', Zeitschrift für Kunstgeschichte 66 (2003), pp. 524-32.

Itineraria et alia geographica, ed. by P. Geyer and O. Cuntz, CCSL 175-76, 2 vols, Turnhout 1965. 
Jacobs, Andrew S., Remains of the Jews. The Holy Land and Christian Empire in Late Antiquity, Stanford CA 2004.

Jenal, Georg, Italia ascetica atque monastica: das Asketen- und Mönchtum in Italien. Von den Anfängen bis zur Zeit der Langobarden (ca. 150/250-604), Monographien zur Geschichte des Mittelalters 39, Stuttgart 1995.

Jerusalem as Narrative Space/ Erzählraum Jerusalem, ed. by Annette Hoffmann and Gerhard Wolf, Leiden 2012.

Klein, Holger, 'Constantine, Helena, and the Cult of the True Cross in Constantinople' in:Byzance et les reliques du Christ, ed. by Jannic Durand et Bernard Flusin, Paris 2004, pp. 31-59.

Kühnel, Bianca, From the Earthly to the Heavenly Jerusalem. Representations of the Holy City in Christian Art of the First Millennium, RQCAKG Supplementheft 42, Rome, Freiburg and Vienna 1987.

LP: Le Liber Pontificalis. Texte, introduction et commentaire, ed. by Louis Duchesne, 2 vols, Paris 1886-92; Additions et corrections, ed. by C. Vogel, Paris 1957 (Reprint: 3 vols, Paris 1981).

Lidov, A. 'Hierotopy. The Creation of Sacred Spaces as a Form of Creativity and Subject of Cultural History' in: Hierotopy. Creation of Sacred Spaces in Byzantium and Medieval Russia, ed. by A. Lidov, Moscow 2006, pp. 32-58.

_- 'Byzantine Jerusalem. The Imperial Pharos Chapel as the Holy Sepulchre' in: Jerusalem as Narrative Space/Erzählraum Jerusalem, ed. by Annette Hoffmann and Gerhard Wolf, Leiden 2012.

Longo, Umberto, 'Dimensione locale e aspirazioni universali a Roma nel XII secolo: San Giovanni in Laterano come santuario e l'eredità dell'Antica alleanza' in: Expériences religieuses et chemins de perfection dans l'Occident médiéval. Études offertes à André Vauchez par ses élèves ed. by D. Rigaux, D. Russo, and C. Vincent, Paris 2012, pp. 121-37.

Magdalino, Paul, 'L' église du Phare et les Reliques de la Passion à Constantinople (VIIe/ VIIIe-XIIIe siècles)' in: Byzance et les reliques du Christ, ed. by Jannic Durand et Bernard Flusin, Paris 2004, pp. 15-30.

Maraval, Pierre, 'Grégoire le Grand et les lieux saints d'Orient' in: Gregorio Magno e il suo tempo. I:XIX Incontro di studiosi dell'antichità cristiana in collaborazione con l'École française de Rome, Roma 9-12 maggio 199o, Studia Ephemeridis Augustinianum 33, Rome 1991, pp. 65-76.

_- ' 'The Earliest Phase of Christian Pilgrimage in the Near East (before the $7^{\text {th }}$ century)', Dumbarton Oaks Papers 56 (2002), pp. 63-74.

Mathews, Thomas F., The Clash of Gods: A Reinterpretation of Early Christian Art. Princeton NJ 1993.

Matthiae, Guglielmo, Mosaici medioevali delle chiese di Roma, 2 vols, Rome 1967. 
Mondini, Daniela, 'Reliquie incarnate: le "sacre teste" di Pietro e Paolo a San Giovanni in Laterano a Roma' in: Del visibile credere. Pellegrinaggi, santuari, miracoli, reliquie, ed. by D. Scotto and G. Cracco, Florence 2011, pp. 265-96.

New Jerusalems. Hierotopy and Iconography of Sacred Spaces, ed. by Alexei Lidov, Moscow 2009.

Nilgen, Ursula, 'Das Fastigium in der Basilica Constantiniana und vier Bronzesäulen des Lateran', Römische Quartalschrift für christliche Altertumskunde und Kirchengeschichte 72 (1977), pp. 1-31.

Ó Carragáin, Éamonn, Ritual and the Rood. Liturgical Images and the Old English Poems of the Dream of the Rood Tradition, Toronto and Buffalo 2005.

O’Reilly, Jennifer, 'Introduction' in: Bede: On the Temple Translated Texts for Historians 21, transl. with notes by Seán Connolly, Liverpool 1995, pp. xvii-lv

-, 'The Art of Authority' in: After Rome, ed. by Thomas Charles-Edwards, Oxford 2003, pp. 141-89.

Studies in Anglo-Saxon Literature and Its Insular Context in Honour of Éamonn Ó Carragáin, ed. by Alistair Minnis and Jane Roberts, Turnhout 2007, pp. 3-29.

Osborne, John, 'The Jerusalem Temple Treasure and the Church of Santi Cosma e Damiano in Rome', Papers of the British School at Rome 76 (2008), pp. 173-81.

Ousterhout, Robert, 'The Temple, the Sepulchre, and the Martyrion of the Savior', Gesta 29 (1990), pp. 44-53.

_- ' 'Flexible Geography and Transportable Topography' in: The Real and Ideal Jerusalem in Jewish,Christian and Islamic Art, Jewish Art 23/24 (1997-98), ed. by B. Kühnel, Jerusalem 1998, pp. 393-404.

Pullan, Wendy, 'Jerusalem from Alpha to Omega in the Santa Pudenziana mosaic' in: The Real and Ideal Jerusalem in Jewish,Christian and Islamic Art, Jewish Art 23/24 (1997-98), ed. by B. Kühnel, Jerusalem 1998, pp. 405-17.

The Real and Ideal Jerusalem in Jewish,Christian and Islamic Art, Jewish Art 23/24 (199798), ed. by B. Kühnel, Jerusalem 1998.

Sahner, Christian C. 'Hierusalem in Laterano: the Translation of Sacred Space in Fifth Century Rome' in: New Jerusalem/Novye Ierusalimy, Moscow 2009, pp. 103-30.

Saxer, Victor, Sainte-Marie-Majeure.Une basilique de Rome dans l'histoire de la ville et de son église (Ve-XIIIe siècle), CÉFR 283, Rome 2001.

Smith, J.C., 'Form and Function of the Side Chambers of Fifth- and Sixth-Century Churches in Ravenna', Journal of the Society of Architectural Historians 49, no. 2 (1990), pp. 181-204.

Thraede, Klaus, 'Jerusalem II' in: Reallexikon für Antike und Christentum 17, Stuttgart 1996, cc. 718-64.

Thunø, Erik, Image and Relic. Mediating the Sacred in Early Medieval Rome, ARID-S 32, Rome 2002. 
Tongeren, Louis van, Exaltation of the Cross. Toward the Origins of the Feast of the Cross and the Meaning of the Cross in Early Medieval Liturgy, Liturgia condenda 11, Leuven 2000.

Vannutelli, Vincenzo, 'La santa colonna che si venera in Roma a S. Prassede: conferenza archeologica tenuta domenica 16 febbraio 1896', L'Arcadia 8 (1896) [offprint consulted in Biblioteca Apostolica Vaticana].

Wolf, Gerhard, 'Laetare filia Sion: ecce ego venio et habitabo in medio tui; images of Christ', in: The Real and Ideal Jerusalem in Jewish,Christian and Islamic Art, Jewish Art 23/24 (1997-98), ed. by B. Kühnel, Jerusalem 1998, pp. 418-29.

Wortley, John, 'The Legend of Constantine the Relic-Provider' in: Daimonopylai: Essays in Classics and the Classical Tradition presented to Edmund G. Berry, ed. by Rory B. Egan and Mark A. Joyal, Winnipeg 2004, pp. 487-96. 
PART 2

Imitation and Translocation 